The University of San Francisco

USF Scholarship: a digital repository @ Gleeson Library | Geschke Center

2019

\title{
Confederation of African Football
}

Michael Goldman

Mlondi Mashinini

Follow this and additional works at: https://repository.usfca.edu/sm

Part of the Sports Management Commons, and the Sports Studies Commons 
Confederation of African Football

History and organization of CAF

Before the establishment of the Confederation of African Football (CAF) in 1957, football management in Africa had been a colonial endeavor, driven by missionaries and colonial governments. By 1954, Egypt, Sudan, Ethiopia, and South Africa had joined FIFA and were represented at the $29^{\text {th }}$ FIFA Congress in Switzerland. Africa was recognized as a FIFA zonal group that year, with Egyptian Abdelaziz Abdallah Salem being elected to represent Africa on the executive committee until a confederation was established. Representatives of Egypt, Sudan, and South Africa met at the 1956 FIFA Congress in Portugal to develop the statutes and regulations for the new confederation and for an Africa Cup of Nations (AFCON). In early 1957, representatives from Ethiopia joined the group for the first Constitutional Assembly of CAF, which was immediately followed by the first AFCON on February 10 (CAF, 2007).

Although football as a "European cultural form" had been used by Christian missionaries, colonial governments, and industrialists to encourage discipline, maintain order, and occupy workers' free time, the game had also been used as part of the resistance to colonial rule (Fletcher, 2017). Football and CAF membership were "vehicles for pan-Africanism" in postcolonial Africa (Fletcher, 2017). National independence in Ghana, Uganda, Nigeria, Kenya, and Zambia was marked by football tournaments featuring their new national teams. For example, Kwame Nkrumah, the first independent President of Ghana, actively used football to promote national and African unity. In this way, the nation-football nexus played an important part of forming a post-colonial identity across Africa. More recently, the "African World Cup" narrative surrounding the 2010 FIFA World Cup in South Africa ${ }^{\mathrm{TM}}$ reinforced the use of football to advance a pan-Africanist cause (Alegi, 2010). The formation of CAF also saw the emergence of a "politically vociferous African constituency” within FIFA (Darby, 2003). 
South Africa was represented at the 1957 founding gathering of CAF by the whites-only Football Association of South Africa (FASA), which had been formed in 1892 as the South African Football Association (SAFA). The racial segregation of sport had been in place in South Africa before the National Party instituted their Apartheid policy of separate development, although the Apartheid government made this segregation explicit under the law. SAFA was the first association in Africa to become affiliated to FIFA in 1910. The anti-Apartheid South African Soccer Federation (SASF) applied for FIFA membership in 1954, arguing that SAFA/FASA did not represent the whole of South African football. Although FIFA agreed with this argument, it rejected SASF's application because there were no white clubs or players included, and confirmed SAFA/FASA's view that segregation was a traditional practice (Fletcher, 2017).

South Africa did not participate in the first Africa Cup of Nations in 1957 and was formally expelled from CAF by 1960 after refusing to send a racially integrated team. Fighting Apartheid thus became part of the pan-African identity of CAF (Fletcher, 2017). By 1960, pressure was building on FASA for their refusal to field non-white players, and in September 1961, FASA was suspended from FIFA. After FIFA reinstated FASA's membership, CAF lobbied the Soviet and Asian National Associations, and South Africa was suspended again in 1964. CAF successfully applied pressure again in 1973, this time on Joao Havelange, the head of the Brazilian Football Association, to withdraw the Brazilian team from that year's South Africa Games. Havelange also echoed the "clarion call of African football," to ostracize Apartheid South Africa in his successful FIFA presidential campaign (Darby, 2003).

By early 2018, CAF had 56 members, including Zanzibar and Reunion, that were not yet members of FIFA. CAF therefore had the most members of FIFA's continental confederations. Zanzibar formally submitted their application for FIFA membership in mid-2017, which if accepted would make them the $212^{\text {th }}$ member association. The membership of CAF was structured into six smaller regional zones, covering North Africa, Central Africa, West Africa, East Africa, and Southern Africa. CAF's official languages 
are French, English and Arabic, while Portuguese is also an official language of CAF's General Assembly.

CAF's influence within FIFA increased as more countries gained their independence, and the organization grew to 35 members by 1975, the same number as UEFA at that time. By 2000, CAF had passed 50 members. CAF's successful support for Brazilian Joao Havelange for FIFA President in 1974 also reinforced their growing influence and a shift in power away from Europe. African members of FIFA were responsible for the presidential election of Sepp Blatter in 1998 as the champion of African football, and his re-election in 2002, in spite of the official CAF endorsement of his opponents on both occasions. The 1970 FIFA World Cup saw the first guaranteed place for an African country. By 1998, Africa had five guaranteed berths. After South Africa controversially lost out to Germany to host the 2006 World Cup, a continental rotation system was introduced, resulting in Africa hosting the 2010 tournament.

On the continent, CAF holds the exclusive rights to organize a number of competitions for national teams and club teams. These include:

- the Africa Cup of Nations (AFCON) for national men's teams;

- the African Nations Championship for national men's teams comprised of domesticbased players only;

- the Women's Africa Cup of Nations;

- Futsal Africa Cup of Nations;

- Beach Soccer Africa Cup of Nations; and

- U-23, U-20 and U-17 competitions for men's and women's national sides.

At a club level, CAF hosts the African Champions League, as well as the Confederations Cup for domestic cup winners. Winners of both competitions complete in a one-off match for the CAF Super Cup. 
The hosting of AFCON in January and February every second year has created a difficult club-versus-country conflict, as African athletes playing in Europe are forced to decide between staying with their league club for important mid-season games, or responding positively to their call-up to play for their national team. The 2017 tournament in Gabon saw seven Cameroon players ignoring their country's call, while 12 English Premier League clubs lost over 20 players during the period (BBC, 2017). CAF, under previous president Issa Hayatou, had argued that the weather in different parts of the continent made a mid-year tournament impossible, although some questioned whether this decision was driven more by not wanting to bow to European pressure (BBC, 2017). The new CAF president, Ahmad, supported the idea of shifting the biennial tournament to June and July, and aligned African football more with the European schedule. This change was confirmed by the CAF Executive Committee in July 2017.

\section{Commercialization of football in Africa}

"Football is the only way that we make a living, and we expect that when we play for our countries, we should get a fair share of whatever revenue comes as a result. If the administrators of football fail to recognize this fact things will not run smoothly. Football is not a pastime for us. Its big business."

Lucas Radebe, former captain of South Africa and Leeds United.

Since the mid-1980s, individuals, clubs, national associations, and CAF have increasingly prioritized financial profits (Alegi, 2010). In 1984, private sponsors and commercial advertisements were allowed for the first time in the African Nations Cup. Cameroonian Issa Hayatou's election as CAF president in 1988 increased commercialization of the game in Africa, with FIFA partners adidas and Coca-Cola joining the newly opened categories of alcohol and tobacco (Alegi, 2010). Since then, CAF has enjoyed the support of a number of leading African and global brands, including South Korea's Samsung, Japan’s Nissan, and South Africa's Standard Bank.

Corporate partnerships 
In 2016, CAF signed an 8-year deal with the French multinational Total, to replace the French mobile operator Orange as the title sponsor of the Africa Cup of Nations. Orange had sponsored the Africa Cup of Nations four times since 2010, offering its African customers exclusive mobile and web content. Total's sponsorship covers all CAF's interclub and national competitions, as the international oil and gas company aims to become the local services champion on the continent. According to Jacques-Emmanuel Saulnier, Total’s Senior Vice-President of Corporate Communications:

Africa is a cornerstone of our global presence and a keystone of our 20-year ambition. ...Today, more than 10,000 people work in all of Total's African businesses... each day, we serve two million customers in our 4,200 retail outlets across the continent (Chibelushi, 2017).

Corporate sponsorship has played an important role in the development of football in Africa, including incentivizing players competing in FIFA and CAF tournaments. For example, each member of the Cameroon team participating in the 2002 World Cup received £5,000 for qualifying from Guinness Cameroon. The brewer also offered $£ 1,000$ for the best player in each match, and another $£ 5,000$ for the team if they progressed past the first round (Schatzberg, 2006).

Outside of the traditional energy, financial services, telecommunications, and consumer goods brands that have invested in football across the continent, online sports betting companies have also recently become more prominent. The most active of these has been SportPesa, a Kenyan company founded in 2014 by local and international investors, including the CEO, Captain Ronald Karauri, the former Chairman of the Kenya Airline Pilots Association. By early 2018, the company operated in Kenya, Tanzania, South Africa, Italy and the United Kingdom. SportPesa's association with African football began with a \$4.36 million title sponsorship of the Kenyan Premier League in 2015, followed by deals with the Kenyan Football Federation as well as two of the biggest clubs in Kenyan football, Gor Mahia and AFC Leopards. The company also sponsors Simba SC and Singida 
United of the Tanzanian Premier League, and the South African football club Cape Town City F.C. SportPesa became the first Kenyan company to sponsor an English Premier League team, when it announced a 3-year sponsorship deal with Hull City in 2016, which was the most lucrative in the club's 112-year history. This deal was followed by agreements with Southampton FC and Everton Football Club. SportPesa's sponsorships in Kenya were called into question in June 2017, however, when Kenyan President Uhuru Kenyatta signed a new finance bill into law, which included a new 35\% tax rate on all gambling revenue, in addition to the existing 30\% corporate tax. Should the new law take effect in early 2018, SportPesa's Karauri has threatened to withdraw all sports sponsorships of Kenyan teams.

Private capital has also introduced new entrepreneurs and business leaders to the administration of football in Africa. In Cameroon, for example, Coton Sport FC de Garoua was founded in 1986 as a workers' social team for Societe de Developpement du Coton (Sodecoton), Cameroon's state enterprise to manage the cotton sector. Since joining Cameroon's first division in 1993, the club has dominated the domestic tournament, winning fourteen national championships, six Cameroon Cups, and being runners-up in the CAF Cup in 2003 and CAF Champions League in 2008. Coton Sport enjoyed the financial and management support of Sodecoton until new leadership questioned the role of forprofit sports activities in 2014. An employee-owned mutual association with a board of directors and executive office was subsequently set up to manage the club, which operates with monthly financial contributions from employees.

Alegi (2010) highlighted the role of South African Patrice Motsepe, a lawyer turned entrepreneurial mining magnate, who bought Mamelodi Sundowns FC in 2003. The club was founded in 1970 by a group of young local footballers, and competed modestly in racially segregated domestic leagues before being signed up for the new multi-racial National Soccer League in 1985 by their new owner, Zola Mahobe. Thirty-one-year-old Mahobe, then a flamboyant black businessman (known as 'Mr. Cool'), bought the struggling team for R100,000 (US\$50,000 at the time) and then spent approximately US\$1 million signing record player and coaching deals, developing appealing media brands for his players and the club, and incentivizing his team with expensive gifts and trips (Marsh, 
1992). Within three years, Mamelodi Sundowns had won the league title and two cup competitions. Mahobe nurtured his image with a "flashy dress sense: afro, open neck shirts, rings and gold necklaces" (Jacobs, 2014), which would eventually contribute to his undoing when he and his mistress Snowy Moshoeshoe were found guilty of more than US\$3 million in bank fraud in 1989. When the club was repossessed by Standard Bank, which Mahobe had defrauded, it was bought by gambling tycoon Abe Krok, with the support of the Greek immigrant football couple Anastasia and Angelo Tsichlas. During the following 14 years, Sundowns continued to dominate domestic league and cup competitions, and reached the final of the CAF Champions League in 2001. In 2003, Patrice Motsepe bought the club and "tried to bring back the Mahobe glory days" (Jacobs, 2014). Some reports suggested Mahobe was actually a "silent director" at the club after his release from prison, with Motsepe stating in December 2013 that Sundowns "will be eternally grateful to Mahobe” (Jacobs, 2014). Since Motsepe bought Sundowns, the club has won the domestic league title another four times, earned seven additional cup trophies, and in 2016 won their first CAF Champions League title, followed in 2017 with their first CAF Super Cup title.

Media rights

After Cameroon's impressive quarter-final appearance at the 1990 FIFA World Cup in Italy, CAF changed their TV broadcast rights strategy. The Association went from making the broadcasts of the Africa Cup of Nations and African Champions League available to African public broadcasters for a nominal fee, to selling these rights to the highest bidder (Alegi, 2010). CAF selected Frenchman Jean-Claude Darmon and his MediaFoot agency to manage the sale of TV rights for the Africa Cup of Nations, and then later also the TV and marketing rights for the African Champions League. The latter deal saw over \$2 million of guaranteed prize money available in 1997, partly to incentive the best local footballers to stay in Africa. Television deregulation and technology improvements across Africa contributed to the commercial development of football (Alegi, 2010), with direct broadcast satellite technologies broadening the base of television viewers, while providing access to additional commercial channels and offerings. 
The initial TV rights deal with Jean-Claude Darmon in 1990 was extended in 1997, and then renewed until 2008 through a new \$50 million contract. Darmon merged with Canal Plus and RTL to form Sportfive in 2002, and guaranteed CAF a minimum of almost $\$ 140$ million from 2008 to 2016. In mid-2015, CAF extended their marketing and media rights deal with Sportfive until 2028. The new deal guaranteed $\$ 1$ billion to CAF, and covered the Africa Cup of Nations, the African Nations Champions, the CAF Champions' League, the Confederations Cup, the Super Cup, and the African U-20 and U-23 Championships.

Although CAF's new media rights strategy resulted in additional resources and private investment, it meant that many football viewers missed out on seeing their clubs and national teams competing. For example, millions of viewers in Guinea Bissau, Malawi, and the Republic of Congo could not watch the 2006 Africa Cup of Nations when their state broadcasters were unable to pay the higher provider fees (Alegi, 2010). In this way, African football experienced both the positive and negative impacts of the "international media-business-sport alliance" that characterizes the business of football (Cornelissen, 2010).

Another example of this media-driven alliance is SuperSport International, which was established in South Africa in 1988 as the sports segment of M-Net, the country's first pay TV channel. Initially the content focus was on rugby, along with cricket, golf, boxing, cycling, and English Premier League football, but in 1994 M-Net bought Pretoria City Football Club and rebranded the team SuperSport United F.C. In 2007, SuperSport, then a multichannel pay TV network within Multichoice South Africa, won the rights to the South African Premier Soccer League (PSL) in a five-year deal worth \$200 million. The broadcast deal did require some football games to be broadcast on SABC, the domestic free-to-air channel, however. Given the commercial success of the deal for Multichoice's new more-affordable Compact package, the PSL deal was renewed in 2011 for \$277 million until the 2017/18 season. By December 2017, the tender process for the next set of rights was still under consideration. The chairman of the PSL, Dr. Irvin Khoza, reflected on the 10-year partnership: 
The relationship was a defining moment for the industry in this country. It's been far more than a mere investment in the PSL. Development has benefitted too, with club academies producing top players. I commend SuperSport for their courage, for being so single-minded, for understanding.... They had the inner spirit to help bring out the best of the immense talent available in our country (SuperSport, 2017).

SuperSport reportedly funded approximately $70 \%$ of all sub-Saharan sport, including purchasing broadcast rights, upskilling league administrators and production crews in each territory, as well as improving facilities and helping federations acquire sponsors (Naspers, 2014). For example, the Multichoice Diski Challenge PSL Reserve League (MDC), a multi-pronged corporate social responsibility program, was launched in South Africa in August 2014. The MDC comprised a league competition for the PSL academy clubs; player life skills and development; player scholarships for study purposes; an internship programme to develop broadcasting skills among youth; and the broadcast of MDC matches on community TV channels available on Multichoice. In January 2017, the PSL Chairman Irvin Khoza reported that 23 players had advanced from the MDC to the PSL. Additionally, South African PSL clubs earned a monthly grant of \$100,000 directly from the SuperSport broadcast deal, while national First Division teams earned $\$ 40,000$ monthly.

Beyond South Africa, SuperSport acquired the broadcasting rights of Africa's most popular domestic leagues in Nigeria, Ghana, Kenya, Zambia and Zimbabwe. Yet despite being seen as having a symbiotic relationship with football in Africa, in November 2016 the broadcaster declined to renew its sponsorship of the Ghana Premier League. After 10 years of involvement, SuperSport also terminated their contract with the Kenyan Premier League (KPL) in March 2017, due to a dispute between the KPL and Football Kenya Federation about which was recognized by FIFA to administer professional football in Kenya (Kwalimwa, 2017). In April 2017, SuperSport also terminated its broadcast deal with Nigeria’s Professional Football League organisers, League Management Company, citing a breach of contract as the reason for the termination. League officials later suggested that 
the breach was due to a lack of foreign exchange and the weakness of the Nigerian Naira against the U.S. Dollar.

The development of football media rights in Africa and abroad therefore impacted domestic fandom and viewership both positively and negatively (Frimpong, 2014). Analysts suggested that the appeal of European leagues lay in the level of elite on-field performance, the television production quality, the entertainment atmosphere in iconic sporting facilities, and the participation of many of the best footballers in the world (Alegi, 2010). In this sense, the extensive broadcasts of European football in Africa served as a form of "electronic colonialism" (Gerard Akindes in Alegi, 2010), which contributed to the substitution of domestic attendance and viewership with European viewership (Bankole, Olaniyan, Babatunde, \& Nghargbu, 2012). For example, SuperSport paid four times as much for English Premier League (EPL) rights in sub-Saharan Africa than it paid to broadcast domestic South African Premier Soccer League games. By early 2018, SuperSport was the English Premier League's longest-serving international partner, and had signed on until the end of the 2021/22 season. In 2004, EPL sponsor Barclays attracted 24,000 people to watch a live game on a big screen in South Africa, which was four times the average attendance at domestic league matches.

Political and social dimensions of football management in Africa

Alegi (2010) highlighted the negative impacts of privatization of African football, including the intensifying competitive imbalances, accelerating migration abroad, and increasing corruption. After independence, African countries unsuccessfully attempted to end the migration of their best players to Europe. Previously, European countries, especially France, Portugal and Belgium, had transferred players from their colonies to club and sometimes national teams in Europe. This trend continued after the end of colonial rule in Africa, with an estimated 350 Africans playing first or second division football in Europe by 1995 (Darby, Akindes, \& Kirwin, 2007). That year’s Bosman ruling in Europe relaxed the quota on foreign players in European leagues, which saw this number grow to 571 players in Europe by 2009 (Besson, Poli, \& Ravenel, 2010). By October 2015, over 
3,700 African expatriate footballers were playing for one of the world's 6,135 clubs, making up almost $20 \%$ of expatriate footballers at the time. Nigeria provided the largest number of African players in other leagues (596), followed by Senegal (377), Cote d'Ivoire (370), Cameroon (366), and Ghana (365), together contributing 24\% of the top 15 exporter countries (Poli, Ravenel, \& Besson, 2015). Over 35\% of the combined squads of France and Portugal competing in the Euro 2016 final featured players with African roots (Aarons, 2016).

In 2003, Sepp Blatter expressed a view about football migration from Africa that numerous scholars had previously argued, describing the European clubs that benefited as:

...neo-colonialists who don't give a damn about heritage and culture, but engage in social and economic rape by robbing the developing world of its best players. Dignity and integrity tend to fall by the wayside in what has become a glorified body market (Bradley, 2003).

Given his ethics violations and subsequent banning from all football-related activities in 2015, ironically Blatter also added: "If we are not careful, football may degenerate into a game of greed - a trend I will vigorously oppose” (Bradley, 2003). The United Nations Commission on Human Rights highlighted the "danger of effectively creating a modern day 'slave trade"” (Bale, in Darby et al., 2007) in their study of the migration, and sometimes illegal abandonment, of younger African footballers. Darby et al. (2007) argued that football migration has been:

...interpreted as a form of neocolonial exploitation in that it involves the sourcing, refinement and export of raw materials... for consumption and wealth generation in the European core and that this process results in the impoverishment of the African periphery (emphasis in the original).

The difficult socioeconomic and political environments facing many African countries has also hampered efforts by some well-organized professional African clubs and leagues to 
provide the regular, guaranteed salaries and labor protection promised in Europe. The very substantial differences in club budgets and player salaries between African clubs and those in Europe increase the appeal for talented footballers.

CAF initially responded by banning players from competing in the Africa Cup of Nations if they played internationally. Issa Hayatou believed that the African Champions League also created economic incentives to retain African talent, although he argued in 1999:

...CAF cannot do anything. It is the responsibility of the national federations to come up with some kind of legislation to regulate this process. CAF cannot intervene in this matter, but we could advise them to avoid the exploitation of African talents to enrich the football of the countries above our continent (Darby et al., 2007).

FIFA's Regulations for the Status and Transfer of Players (RSTP) in 2001 included a provision that only allowed European countries to sign players under the age of 18 if the player moved to Europe for reasons unrelated to football, and made provision for clubs involved in the training and education of players between the ages of 12 and 23 to receive compensation from the buying club (Lembo, 2011). Besides the illegal practices of European clubs creating jobs for parents in order to bypass the regulations, clubs also used a 2009 Court for the Arbitration of Sport ruling, which allows the transfer of minors if an exchange agreement is in place with a foreign club. This has resulted in partnerships between European clubs and African clubs, which is the second of the four broad types of academies that Darby et al. (2007) identified.

Football academies in Africa

Darby et al.'s (2007) classification of four broad types of academies included African academies, which are similar to those in Europe but are organized and run by African club teams or national federations; Afro-European academies, which are partnerships between an existing African academy and European club, or where the partnership is developed 
through the European club's acquisition of the African club; well established corporatesponsored academies supported by private individuals or companies; and "nonaffiliated, improvised" ad hoc academies that lack well qualified staff or proper facilities (Darby et al., 2007).

MimoSifcom, the successful academy of Association Sportive des Employes de Commerce (ASEC) Mimosas in Cote d'Ivoire, is a well-known example of the first type of academy, although it was originally set up as joint venture with AS Monaco (Alegi, 2010). As one of the first structured football academies in sub-Saharan Africa, MimoSifcom provided players between the ages of 13 and 17 with both a football and an academic education (Darby et al., 2007). Although the goal was to produce elite players for ASEC Mimosas' professional team and the Ivorian national team (Alegi, 2010), the academy also sold their most talented players to European teams to recoup the costs involved in training and educating the players (Darby et al., 2007). These players include Salomon Kalou of Feyenoord, Chelsea, Lille, and Hertha; Yaya Toure of Olympiacos, Monaco, Barcelona, and Manchester City; and his brother Kolo Toure of Arsenal, Manchester City, Liverpool, and Celtic, who reflected: "I feel very lucky to have been part of the academy, because for Africa, the facilities were very good. It formed me a lot as a player, and as an adult” (World Soccer, 2008).

In neighboring Ghana, the Dutch club Feyenoord partnered with the Ghanian Sports Ministry and local tribal chiefs in the Gomoa Fetteh area to establish the Feyenoord Fetteh Football Academy in 1999. As suggested by this second category of academies, its purpose was to provide a steady stream of raw talent to the Dutch club (Darby et al., 2007), although by 2009 only one player had signed with Feyenoord (Alegi, 2010). That same year, Wienco, a Dutch-Ghanian agricultural company, took over the management of the academy, and in 2014 the academy changed its name to the West Africa Football Academy when it acquired the Red Bull Academy in Ghana.

Nogoom El Mostakbal F.C. is a privately-owned Egyptian professional football club that was founded in 2007. The club is an example of Darby et al.'s (2007) third category of 
academy, as it developed out of a PepsiCo corporate social responsibility project, known as the Pepsi School League. Spain's La Liga partnered with the Pepsi School League and Nogoom El Mostakbal F.C. in 2015 to send the best 23 young Egyptian players to participate in a Royal Andalusian Football Federation camp. By 2015, the project had involved 800,000 students from 7,500 schools in Egypt, with 60 Egyptian professional players having graduated to local and international clubs (Ayyad, 2015). For example, Mohamed Salah made his professional debut for Cairo-based El Mokawloon in 2010 before playing for Basel, Chelsea, and Roma, and then signed a €50 million deal to join Liverpool in mid-2017. Nogoom El Mostakbal F.C. was created to accommodate talented players from the Pepsi School League who were not recruited by other professional teams, and by the end of 2017, the Pepsi-sponsored club was competing in the second division league.

The final category of academies in Africa operate outside of the legal and administrative regulations designed to safeguard young players from unscrupulous agents, and have been established with the primary interest of personal financial gain rather than football or educational development (Darby et al., 2007). Players identified by noncertified agents at these academies are not required to obtain an official letter from their national federation, while the agents are not required to pay a bond to take the players abroad for trial.

\section{Illegal practices}

Alegi (2010) argued that some football administrators in Africa were motivated to create and maintain patronage networks and launch political careers, the opportunities for which increased with privatization. He pointed to "greed, shoddy organization, and callous indifference towards spectator safety" that partly led to the stadium disasters in Ghana, Cote d'Ivoire, South Africa, and the Democratic Republic of the Congo between 2001 and 2009. At a higher level, African football administrators have also been caught up in the illegal practices related to World Cup bidding. As part of the U.S. Department of Justice indictment of FIFA officials in 2015, former FIFA Executive Committee member Chuck Blazer testified that bribes were paid in order to vote for numerous World Cups, including 
the Morocco bids for the 1998 and 2010 tournaments, and the South African bid for 2010 (Gibson \& Lewis, 2015). According to U.S. prosecutors, South Africa paid \$10 million to CONCACAF president Jack Warner in exchange for votes. The head of the South African 2010 Local Organizing Committee, Danny Jordaan, confirmed that \$10 million was paid to CONCACAF, via FIFA, as a contribution to their football development fund, but denied that this was a bribe (Motale, 2015). Officials related to Egypt's bid for the 2010 World Cup also claimed that Warner had solicited $\$ 1$ million for each of the seven votes he promised to deliver, but that they refused to pay (Brown \& Randall, 2015).

Club and league-level sponsorship rights in Africa have provided additional opportunities for illegal practices. For example, a joint $\$ 50$ million sponsorship deal between South Africa's Football Association, the professional league, banking group ABSA, and South African Breweries attracted negative attention when it emerged that five of the football administrators involved in negotiating the deal received \$5 million commission. The chairman of the Premier Soccer League and Vice-President of SAFA defended the payment, suggesting that the administrators "deserve to be rewarded... They have done the best for football... and have acted in the best interest of the PSL” (Cornelissen, 2010).

Alegi (2010) argued that South Africa's new World Cup stadiums could help “debunk stereotyped images of Africa as a primitive, tribal, wild, sick, conflict-ridden, chaotic place populated by kleptocratic tyrants and faceless victims in need of Western help.” The unfortunate reality, however, was that the stadiums presented opportunities for large established local firms to participate in illegal practices. Collusion by World Cup stadium construction companies was estimated to have added $\$ 1$ billion to the costs. By February 2017, seven construction companies had been fined over \$100 million in competition penalties, and had agreed to contribute another $\$ 100$ million to promote black South African ownership in the construction sector (SA News, 2017). In April 2017, the City of Cape Town won a judgement against WBHO in its efforts to recover more than $\$ 40$ million in damages from construction companies that were found guilty of collusion (Etheridge, 2017). 
Another illegal issue that football administrators have had to deal with across the continent is the perception of sorcery. For some fans, players, and administrators, the performance of their club or national team depended on the extent to which 'juju', 'witchcraft', or 'black magic' had been used by the teams. For example, South Africa’s Sports Minister in 2002, Ngconde Balfour, approved 'traditional healers' travelling with the team to that year's World Cup, arguing: "If the Bafana Bafana players believe the efforts of the inyangas help them to play better, they should be assisted by their special doctors... This is a cultural expression” (Schatzberg, 2006). CAF did not want to present a “Third-World” image, and banned all ‘team advisors', ‘wise men', ‘counsellors', ‘technical consultants', and 'morale officers' from any role within the participating teams. African Player of the Year and Bayern Munich’s Samuel Kuffour echoed this view, suggesting: "It is an old belief that has no place in modern football... Juju can never help a player become a superstar. Only hard work, training and discipline will do that” (Schatzberg, 2006). Following a 2003 AFCON qualifier between Rwanda and Uganda, which involved a well-publicized incident of perceived sorcery, the Federation of Uganda Football Association (FUFA) committed to "trying to find a way in which we will educate fans and all those concerned that juju does not work in football” (Schatzberg, 2006).

Recommendations and implications

Madichie (2010) lamented the lack of scholarship on football's contribution to economic development in Africa. Beyond this topic, academic research at the intersection of football, business, and management is limited, especially in quality peer-reviewed publications. An opportunity exists for scholars across Africa’s three main languages, French, English and Arabic, to collaborate on research projects to investigate a range of important questions. This chapter points to the need to further investigate the relationship between organizational design and leadership practices, and the development of the game. With the recent realignment of African football to the European schedule, it may be important to examine the impact on African players at home and abroad. Although some initial analysis has taken place to understand the substitution effect of international football media, limited guidance exists on appropriate mitigation strategies or policy options. Lastly, the difficult 
issues of migration and the role of football academies demands further research, especially in terms of ethical and sustainable practices.

This chapter's implications for football administrators and related managers is to consider the diversity and complexity of Africa's 56 football territories. As demonstrated by the experiences of previous FIFA presidential candidates, viewing the continent as a single entity is dangerous. Industry practitioners should also take note of the limited published resources related to the business of football in Africa, suggesting a need to build quality business relationships in order to more deeply understand the local dynamics. A final implication of this exploration of African football is that the game engages a substantial majority of the continent's population, and therefore presents compelling partnership opportunities.

Reference list

Aarons, E. (2016). France's and Portugal's colonial heritage brings African flavor to Euro 2016. The Guardian, [online]. Available at https://www.theguardian.com/football/2016/jul/09/france-portugal-colonial-historyafrican-flavour-euro-2016 [Accessed 30 Nov. 2017]. 
Alegi, P. (2010). African Soccerscapes: How a Continent Changed the World's Game. Athens: Ohio University Press.

Ayyad, M. (2015). PepsiCo considers developing Pepsi league for students in Egypt: Ahmed El-Sheikh. Daily News Egypt, [online]. Available at https://dailynewsegypt.com/2015/01/25/pepsico-considers-developing-pepsi-leaguestudents-egypt-ahmed-el-sheikh/ [Accessed 30 Nov. 2017].

Bankole, A., Olaniyan, O., Babatunde, M. A. and Nghargbu, R. (2012). Does crossborder broadcast of foreign football change the demand pattern of domestic recreation? Empirical study of imports of audiovisual services through digital satellite television. Journal of International Trade Law and Policy, 11(2), pp. 191-211.

BBC. (2017). Africa Cup of Nations: CAF considers June or July move. [online] Available at http://www.bbc.com/sport/football/40645125 [Accessed 30 Nov. 2017].

Besson, R., Poli, R. and Ravenel, L. (2010). Demographic Study of Footballers in Europe. [online] Neuchâtel: CIES. Available at http://www.footballfordevelopment.net/uploads/tx_drblob/storage/Poli_migration-ofAfrican-football-players_01.pdf [Accessed 30 Nov. 2017].

Bradley, M. (2003). Blatter takes swipe at G-14 “colonialists.” The Guardian, [online]. Available at https://www.theguardian.com/football/2003/dec/18/newsstory.sport8 [Accessed 30 Nov. 2017].

Brown, L. and Randall, N. (2015). Fifa corruption: 'Morocco won 2010 World Cup vote not South Africa' - as it happened. The Telegraph, [online]. Available at http://www.telegraph.co.uk/sport/football/fifa/11657595/Fifa-corruption-Morocco-2010World-Cup-vote-live.html [Accessed 30 Nov. 2017].

CAF. (2007). CAF Official Magazine: Special Edition. Egypt: Nubar Cairo. 
Chibelushi, W. (2017). Talking to Total: Africa Cup of Nations sponsorship 2017. African Business Review, [online]. Available at http://www.africanbusinessreview.co.za/finance/2708/Talking-to-Total:-African-Cup-ofNation-sponsorship-2017 [Accessed 30 Nov. 2017].

Cornelissen, S. (2010). Football's tsars: proprietorship, corporatism and politics in the 2010 FIFA World Cup. Soccer \& Society, 11(1-2), pp. 131-143.

Darby, P. (2003). Africa, the FIFA Presidency, and the Governance of World Football: 1974, 1998, and 2002. Africa Today, pp. 3-24.

Darby, P., Akindes, G. and Kirwin, M. (2007). Football Academies and the Migration of African Football Labor to Europe. Journal of Sport \& Social Issues, 31(2), pp. 143-161.

ESPN. (2017). Africa Cup of Nations expansion and move to summer ratified by CAF. [online] Available at http://www.espn.com/soccer/african-nationscup/story/3161458/africa-cup-of-nations-expansion-ratified-by-caf [Accessed 30 Nov. 2017].

Fletcher, M. (2017). Confederation of African Football. In: J. Hughson, K. Moore, R. Spaaij, and J. Maguire, eds., Routledge Handbook of Football Studies, $1^{\text {st }}$ ed. London: Routledge, pp. 423-431

Etheridge, J. (2017). Court rules in Cape Town's favour in stadium collusion case. News24, [online]. Available at https://www.news24.com/SouthAfrica/News/court-rulesin-cape-towns-favour-in-stadium-collusion-case-20170402 [Accessed 30 Nov. 2017].

Frimpong, K. (2014). Wooing fans back into Ghana stadia - in the wake of globalization of football. Emerald Emerging Markets Case Studies, 4(4), pp. 1-17. 
Gibson, O. and Lewis, P. (2015). Fifa informant Chuck Blazer: I took bribes over 1998 and 2010 World Cups. The Guardian, [online]. Available at https://www.theguardian.com/football/2015/jun/03/fifa-chuck-blazer-bribes-world-cup [Accessed 30 Nov. 2017].

Jacobs, S. (2014). Mr Big Bucks and the Mamelodi Sundowns. [online] Roads \& Kingdoms. Available at http://roadsandkingdoms.com/2014/mr-big-bucks-and-themamelodi-sundowns/ [Accessed 30 Nov. 2017].

Kwalimwa, D. (2017). SuperSport, Kenyan Premier League end partnership. Daily Nation, [online]. Available at http://www.nation.co.ke/sports/football/SuperSport-KPLend-partnership/1102-3881134-iy09kyz/index.html [Accessed 30 Nov. 2017].

Lembo, C. (2011). FIFA Transfer Regulations and UEFA Player Eligibility Rules: Major Changes in European Football and the Negative Effect on Minors. Emory International Law Review, [online] 25(1), pp. 539-585. Available at http://law.emory.edu/eilr/content/volume-25/issue-1/comments/fifa-transfer-regulationsuefa-eligibility-rules-european-football-minors.html [Accessed 30 Nov. 2017].

Madichie, N. O. (2010). Giving the Beautiful Game a "Pretty Bad Name: A viewpoint on African Football. African Journal of Business and Economic Research, 5(1), pp. 135-151.

Marsh, R. (1992). Famous South African Crimes: An investigation into 26 of South Africa's most famous crimes 1900 - 1988, [online] Cape Town: Struik Publishers. Available at www.africacrime-mystery.co.za/books/fsac/chp23.htm [Accessed 30 Nov. 2017].

Motale, P. (2015). Danny: Yes, we paid R120m. The Sunday Independent, [online]. Available at https://www.iol.co.za/sport/soccer/danny-yes-we-paid-r120m1865523\#.VWr72M_BzRY [Accessed 30 Nov. 2017]. 
Naspers (2014). Pay Television. [online] Available at http://www.naspersreports.com/2014/per-op-pay.php [Accessed 30 Nov. 2017].

Poli, R., Ravenel, L. and Besson, R. (2015). Exporting countries in world football. CIES Football Observatory Monthly Report No. 8. [pdf] Neuchâtel: CIES. Available at http://www.football-observatory.com/IMG/pdf/mr08_eng.pdf [Accessed 30 Nov. 2017].

Poli, R., Ravenel, L. and Besson, R. (2017a). World expatriate footballers. CIES Football Observatory Monthly Report No. 25. [pdf] Neuchâtel: CIES. Available at http://www.football-observatory.com/IMG/sites/mr/mr25/en/ [Accessed 30 Nov. 2017].

Poli, R., Ravenel, L. and Besson, R. (2017b). Demographic study of European football (2009-2017). CIES Football Observatory Monthly Report No. 29. [pdf] Neuchâtel: CIES. Available at http://www.football-observatory.com/IMG/sites/mr/mr29/en/ [Accessed 30 Nov. 2017].

SA News. (2017). Collusion implicated construction companies making amends. [online] Available at http://www.bizcommunity.com/Article/196/494/157626.html [Accessed 30 Nov. 2017].

Schatzberg, M. G. (2006). Soccer, science, and sorcery: causation and African football. Afrika Spectrum, 41(3), pp. 351-369.

SuperSport. (2017). SuperSport, PSL celebrate 10-year partnership. [online] Available at https://www.supersport.com/football/absa-

premiership/news/170130/supersport_psl_celebrate_10year_partnership [Accessed 30 Nov. 2017].

Tolsi, N. (2010). Field of Shattered Dreams. Mail \& Guardian, [online]. Available at: http://www.mg.co.za/article/2010-05-07-field-of-shattered-dreams [Accessed 30 Nov. 2017]. 
World Soccer. (2008). Kolo Toure on his African Nations adventure. [online] Available at http://www.worldsoccer.com/features/kolo-toure-on-his-african-nations-adventure174537 [Accessed 30 Nov. 2017]. 